\title{
Iron complexes of chiral phenol-oxazoline ligands: Structural studies and oxidation catalysis
}

\author{
Meenal D. Godbole a, Marisa Prat Puig a , Stefania Tanase ${ }^{\text {a }}$, Huub Kooijman ${ }^{\text {b, }}$ \\ Anthony L. Spek ${ }^{\mathrm{b}}$, Elisabeth Bouwman ${ }^{\mathrm{a}, *}$ \\ ${ }^{a}$ Leiden Institute of Chemistry, Gorlaeus Laboratories, Leiden University, P.O. Box 9502, 2300 RA Leiden, The Netherlands \\ ${ }^{\mathrm{b}}$ Bijvoet Center for Biomolecular Research, Crystal and Structural Chemistry, Utrecht University, The Netherlands
}

Received 12 September 2006; accepted 14 October 2006

Available online 27 October 2006

\begin{abstract}
Iron complexes of two ligands, $\mathrm{HphoxCOOH}$ and $\mathrm{Hphox} i \mathrm{Pr}$, have been synthesized and characterized by crystal structure analyses. The complexes $\left(\mathrm{HNEt}_{3}\right)_{2}\left[\mathrm{Fe}(\text { phoxCOO })_{2}\right]\left(\mathrm{ClO}_{4}\right)$ and $\left[\mathrm{Fe}(\text { phox } i \mathrm{Pr})_{3}\right]$ are reported. Reactions of the ligands rac-HphoxCOOH and racHphox $i$ Pr with iron(II) or iron(III) perchlorate result in the formation of iron(III) complexes with pseudo-octahedral geometry around the metal center. The iron complex obtained from rac-HphoxCOOH crystallized in the centrosymmetric space group Cmca. The two ligands are bound in a tridentate manner generating a meridional coordination with both dianionic ligands on a metal center having the same chirality; due to the center of symmetry the complex with opposite chirality is also present. The complex $(\mathrm{HNEt})_{3}\left[\mathrm{Fe}\left(\mathrm{phox}_{-}\right.\right.$ $\left.\mathrm{COO})_{2}\right]\left(\mathrm{ClO}_{4}\right)$ is the first accurate structural model of the iron complex of a siderophore analog commonly observed in mycobactins. The three didentate ligands in the complex $\left[\mathrm{Fe}(\operatorname{phox} i \mathrm{Pr})_{3}\right]$ are bound with like atoms in a meridional manner to the metal center. The metal ion is surrounded by two ligands of the same chirality and one ligand of opposite chirality (ie. $R R S$ or $S S R$ ); due to the presence of a center of symmetry both isomers are present in the crystal structure. The complex $\left(\mathrm{HNEt}_{3}\right)_{2}\left[\mathrm{Fe}\left(\mathrm{phoxCOO}_{2}\right](\mathrm{ClO})_{4}\right)$ shows promising activity in the oxidation of alkanes, such as toluene, ethylbenzene and cumene, while the complex $\left[\mathrm{Fe}(\mathrm{phox} i \mathrm{Pr})_{3}\right]$ does not show any catalytic activity in alkane oxidations under the conditions tested. The complex $\left(\mathrm{HNEt}_{3}\right)_{2}\left[\mathrm{Fe}(\text { phoxCOO})_{2}\right]\left(\mathrm{ClO}_{4}\right)$ is reasonably efficient in the conversion of $\mathrm{H}_{2} \mathrm{O}_{2}$ to oxidation products.
\end{abstract}

(C) 2006 Elsevier B.V. All rights reserved.

Keywords: Iron; Alkane oxidations; X-ray analysis; Siderophore analogs; Chirality

\section{Introduction}

Iron-containing biological molecules are known to play an essential role in a series of metabolic transformations. For example, P-450 selectively oxidizes the long aliphatic side chain of cholesterol, while methane monooxygenase converts methane to methanol [1-4]. In both cases, an aliphatic $\mathrm{C}-\mathrm{H}$ bond is oxidized to give an alcohol product that is liable to further transformations. Structural and functional modeling of these enzymes can be achieved

\footnotetext{
${ }^{*}$ Corresponding author.

E-mail address: bouwman@chem.leidenuniv.nl (E. Bouwman).
}

through development of small-molecule analogs. The synthetic and catalytic studies on such compounds can assist in increasing the understanding of biological reaction mechanisms and to develop new and more efficient catalysts for several of these industrially attractive reactions [5].

The study of catalytic oxidation reactions by iron or manganese complexes with phenol-oxazoline (Hphox) ligands is a topic of research in our group [6-10]. The phenol-oxazoline ligands have N,O-donor groups for coordination to the metal center. The stability of these ligands has been proposed to be higher than that of similar ligands containing a $\mathrm{C}=\mathrm{N}$ moiety (salen-type ligands), as the oxazoline ring is more stable towards oxidative attack [11]. 


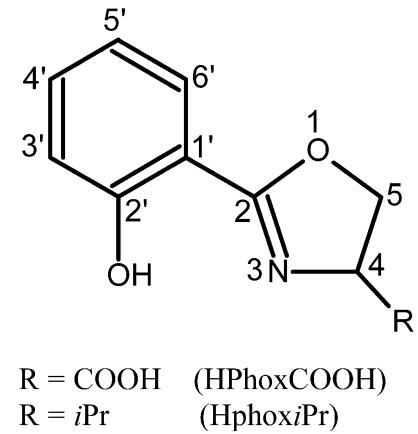

Fig. 1. Schematic drawing of the ligands.

The ligands of the type Hphox $(\mathrm{R}=\mathrm{COOH}, i \operatorname{Pr} ; i \operatorname{Pr}=$ iso-propyl, see Fig. 1) contain a stereogenic carbon center (C4). When the ligand coordinates to a metal ion, the substituents at the stereogenic carbon are closest to the metal center. These substituents can, therefore, sterically affect the approach of molecules towards the metal center and hence induce selectivity. The ligands of the type $S$-HphoxCOOR $\left(\mathrm{R}=\mathrm{H}, \mathrm{CH}_{3}\right.$ ) have been studied initially by Black and Wade [12] in relation with the synthesis of mycobactins and their chelating analogues. Both the racemic $(R S)$, as well as the chiral ligands $(R$ or $S$ ) can be synthesized in straightforward synthetic procedures from the corresponding amino alcohols or derivatives that are commercially available.

In iron-catalyzed catalytic alkane/alkene oxidations carboxylic acids have been frequently used as an additive to increase the catalytic activity [13-16]. The mechanism by which these additives influence the catalytic activity is unclear as yet. Therefore, the Hphox $\mathrm{COOH}$ ligand containing a carboxylate arm that can bind to the metal center has been used in this study. The purpose of the research presented in this paper is to study the coordination behaviour of the ligand Hphox$\mathrm{COOH}$ with iron and examine the activity of its iron complexes in catalytic alkane oxidations and as a model for iron complexes commonly observed in mycobactins. Comparative studies using the ligand HphoxiPr have assisted in elucidating the relation of the activities of the iron complexes with respect to the structures and the electronic effects of the ligands.

\section{Experimental}

\subsection{Physical measurements}

Elemental analyses were performed with a Perkin-Elmer series II CHNS/O analyzer 2400. Infrared spectra (4000$300 \mathrm{~cm}^{-1}$ ) were recorded using the reflectance technique on a Perkin-Elmer Paragon 1000 FTIR spectrometer equipped with a Golden Gate ATR device. Diffuse reflectance spectra were obtained on a Perkin-Elmer Lambda 900 spectrophotometer using $\mathrm{MgO}$ as a reference. A Hewlett Packard 5890 Series II gas chromatograph, equipped with WCOT fused silica column (stationary phase: CPWas 58 (FFAP) CB) and coupled to a Hewlett Packard 5971 series mass spectrometer with a mass-selective detector was used for analysis of the oxidation experiments.

\subsection{Syntheses}

Caution! Perchlorate complexes are potentially explosive and should be handled with appropriate care. The following abbreviations are used throughout the text: Hphox$\mathrm{COOH}=2-\left(2^{\prime}\right.$-hydroxyphenyl)-oxazoline-4-carboxylic acid, and $\operatorname{Hphox} i \operatorname{Pr}=2-\left(2^{\prime}\right.$-hydroxyphenyl)-4-isopropyloxazoline. All reagents and solvents were obtained from Acros or Sigma-Aldrich, and were used with no attempt to remove water or molecular oxygen. Racemic serine and 2-amino-3-methylbutan-1-ol were ordered from Acros and were used as received. The ligands $r a c-\mathrm{HphoxCOOH}$ [12] and $r a c-H p h o x i \operatorname{Pr}$ [17] were synthesized using published procedures.

\subsection{1. $\left(\mathrm{HNEt}_{3}\right)_{2}\left[\mathrm{Fe}(\text { phox } \mathrm{COO})_{2}\right]\left(\mathrm{ClO}_{4}\right)$}

Solid iron(II) perchlorate $(0.308 \mathrm{~g} ; 1.21 \mathrm{mmol})$ was added to a solution of rac-HphoxCOOH $(0.5 \mathrm{~g}, 2.41 \mathrm{mmol})$ in $\mathrm{MeOH}(15 \mathrm{~mL}) . \mathrm{NEt}_{3}(1 \mathrm{~mL})$ was added to the solution. The resulting red-purple solution was warmed to $50{ }^{\circ} \mathrm{C}$ and stirred for $30 \mathrm{~min}$. The solution was filtered and crystals were grown in a few days by layering the $\mathrm{MeOH}$ solution with a mixture of THF/pentane $(1: 1, \mathrm{v} / \mathrm{v})$. The crystalline product was collected by filtration, washed with $\mathrm{MeOH}$ and pentane, respectively, and dried in air. Yield: $55 \%(0.51 \mathrm{~g})$. UV/Vis (solid): $\lambda_{\max }=352,510 \mathrm{~nm}$. IR (diamond): $3016(\mathrm{~b}), 2659$ (m), 1607(vs), 1585(vs), 1544(s), 1468(s), 1436(s), 1371(s), 1317(s), 1245(vs), 1162(s), 1089(vs), 929(s), 847(s), 761(vs), 696(s), 622(s), 608(m), 590(m), 565(m), 429(m), 404(m), $390(\mathrm{~m}), 362(\mathrm{~m}) \mathrm{cm}^{-1}$. Anal. Calc. for $\left(\mathrm{HNEt}_{3}\right)_{2}$ [Fe(phox$\left.\mathrm{COO})_{2}\right]\left(\mathrm{ClO}_{4}\right), \quad\left(\mathrm{C}_{32} \mathrm{H}_{46} \mathrm{ClFeN}_{4} \mathrm{O}_{12}, \quad F_{\mathrm{W}}=770.03\right): \quad \mathrm{C}$, 49.91; H, 6.02; N, 7.28. Found: C, 49.62; H, 6.18; N, 7.32\%.

\subsection{2. mer- $\left[\mathrm{Fe}(\text { phoxiPr })_{3}\right]$}

Solid iron(III) perchlorate $(0.08 \mathrm{~g} ; 0.23 \mathrm{mmol})$ was added to a solution of rac-HphoxiPr $(0.1 \mathrm{~g}, 0.49 \mathrm{mmol})$ in $\mathrm{EtOH}(10 \mathrm{~mL})$. Two to three drops of $\mathrm{NEt}_{3}$ were also added to the solution. The resulting wine-red solution was warmed to $50{ }^{\circ} \mathrm{C}$ and stirred for $3 \mathrm{~h}$. The solution was filtered and crystals were grown in a few days by layering the $\mathrm{EtOH}$ solution with $\mathrm{Et}_{2} \mathrm{O}$. The crystalline product was collected by filtration, washed with $\mathrm{EtOH}$ and $\mathrm{Et}_{2} \mathrm{O}$, respectively and dried in air. Yield: $78 \%(0.12 \mathrm{~g})$. UV/VisNIR (solid): $\lambda_{\max }: 369,517 \mathrm{~nm}$ IR (diamond): $3550(\mathrm{w}, \mathrm{b})$, 3064(m), 2954(m), 1608(vs), 1542(s), 1469(s), 1441(s), $1379(\mathrm{~m}), 1335(\mathrm{~s}), 1233(\mathrm{~s}), 1100(\mathrm{~s}), 1064(\mathrm{~s})$, 959(m), 942(m), 925(m), 850(s), 755(s), 693(m), 664(m), 6034(m), $562(\mathrm{~m}), 538(\mathrm{~m}), 387(\mathrm{~s}) \mathrm{cm}^{-1}$. Anal. Calc. for [Fe(phox$i$ Pr $\left.)_{3}\right],\left(\mathrm{C}_{36} \mathrm{H}_{42} \mathrm{FeN}_{3} \mathrm{O}_{6}, F_{\mathrm{W}}=668.58\right): \mathrm{C}, 64.67 ; \mathrm{H}, 6.33$; $\mathrm{N}, 6.29$. Found: C, 64.44; H, 6.66; N, 6.57\%.

\subsection{Catalytic oxidations}

In a typical run, 100 equiv. of $\mathrm{H}_{2} \mathrm{O}_{2}(30 \%$ in water, $50 \mu \mathrm{L})$ were added to an acetonitrile solution $(5 \mathrm{~mL})$ containing $5 \mu \mathrm{mol}$ catalyst and $5 \mathrm{mmol}$ alkane (cyclohexane, 
cyclooctane or adamantane) at room temperature with a final ratio catalyst:substrate: $\mathrm{H}_{2} \mathrm{O}_{2}=1: 1000: 100$. After $180 \mathrm{~min}$ of reaction at $30^{\circ} \mathrm{C}$, aliquots were taken from the reaction mixtures. At this point, chlorobenzene or 1,2-dibromobenzene was added to the reaction mixtures as internal standard and the samples were analyzed by GC-MS. In all cases retention times for product peaks were compared with retention time of commercially available products and the identity of the product was checked with GC-MS.

\subsection{X-ray structure analyses}

Pertinent data for the structure determinations are given in Table 1. Data were collected at $150 \mathrm{~K}$ on a Nonius KappaCCD diffractometer on rotating anode (graphite-monochromated Mo $\mathrm{K} \alpha$ radiation, $\lambda=0.71073 \AA$ ). The unitcell parameters were checked for the presence of higher lattice symmetry [18]. The structures were solved with direct methods using SHELXLS-86 [19]. Refinement on $F^{2}$ was performed with SHELXL-97 [20]. The amine hydrogen atom was located on difference Fourier maps and its coordinates were refined. All other hydrogen atoms were included on calculated positions riding on their carrier atoms. The methyl groups were allowed to rotate along the $\mathrm{C}-\mathrm{CH}_{3}$ bond. One of the ligands in $\left[\mathrm{Fe}(\operatorname{phox} i \mathrm{Pr})_{3}\right]$ displays disorder, which could be described with a two-site model. The occupancy of the minor component was refined to 0.071(2). Mild distance restraints had to be applied to ensure a reasonable geometry. Neutral atom scattering factors and anomalous dispersion corrections were taken from the International Tables for Crystallography [21]. Validation, geometrical calculations, and illustrations were performed with PLATON [22].

Table 1

Crystallographic data for $\left(\mathrm{HNEt}_{3}\right)_{2}\left[\mathrm{Fe}(\text { phoxCOO})_{2}\right]\left(\mathrm{ClO}_{4}\right)$ and $\left[\mathrm{Fe}(\text { phoxi } \operatorname{Pr})_{3}\right]$

\begin{tabular}{lll}
\hline & $\left(\mathrm{HNEt}_{3}\right)_{2}\left[\mathrm{Fe}\left(\mathrm{phoxCOO}_{2}\right]\left(\mathrm{ClO}_{4}\right)\right.$ & {$\left[\mathrm{Fe}(\text { phoxi } \mathrm{Pr})_{3}\right]$} \\
\hline Formula & $\mathrm{C}_{32} \mathrm{H}_{46} \mathrm{ClFeN}_{4} \mathrm{O}_{12}$ & $\mathrm{C}_{36} \mathrm{H}_{42} \mathrm{FeN}_{3} \mathrm{O}_{6}$ \\
$F_{\mathrm{w}}(\mathrm{g} / \mathrm{mol})$ & 770.03 & 668.58 \\
$a(\AA)$ & $30.166(3)$ & $11.2281(10)$ \\
$b(\AA)$ & $19.167(4)$ & $20.947(3)$ \\
$c(\AA)$ & $12.7528(10)$ & $15.106(2)$ \\
$\beta\left({ }^{\circ}\right)$ & & $111.297(10)$ \\
$V\left(\AA^{3}\right)$ & $7373.6(18)$ & $3310.2(7)$ \\
$Z$ & 8 & 4 \\
Space group & $C m c a($ no: 64$)$ & $P{ }_{1} / c($ no: 14$)$ \\
Crystal system & orthorhombic & monoclinic \\
$\rho_{\text {calc }}\left(\mathrm{g} / \mathrm{cm}^{3}\right)$ & $1.3873(3)$ & $1.3416(3)$ \\
$T(\mathrm{~K})$ & 150 & 150 \\
$\left.\mu(\mathrm{Mo} \mathrm{K} \alpha)(\mathrm{mm})^{-1}\right)$ & 0.546 & 0.506 \\
Total reflections & 97220 & 53882 \\
Unique reflections & 4330 & 5999 \\
Parameters & 237 & 445 \\
$R, w R_{2}$ & $0.043,0.110$ & $0.034,0.086$ \\
$S$ & 1.12 & 1.06 \\
\hline
\end{tabular}

\section{Results and discussion}

\subsection{Description of the crystal structures of the complexes $\left(\mathrm{HNEt}_{3}\right)_{2}\left[\mathrm{Fe}(\text { phox COO })_{2}\right]\left(\mathrm{ClO}_{4}\right)$ and $\left[\mathrm{Fe}(\text { phoxiPr })_{3}\right]$}

Crystallographic data for the structures, $\left(\mathrm{HNEt}_{3}\right)_{2^{-}}$ $\left[\mathrm{Fe}(\text { phoxCOO })_{2}\right]\left(\mathrm{ClO}_{4}\right)$ and $\left[\mathrm{Fe}(\text { phox } i \mathrm{Pr})_{3}\right]$ are collected in Table 1. Relevant bond distances and angles for the complexes are collected in Table 2.

ORTEP projections of different orientations of the complex $\left(\mathrm{HNEt}_{3}\right)_{2}\left[\mathrm{Fe}(\text { phoxCOO})_{2}\right]\left(\mathrm{ClO}_{4}\right)$ and the hydrogen bonding interactions are shown in Figs. 2 and 3. In the complex $\left(\mathrm{HNEt}_{3}\right)_{2}\left[\mathrm{Fe}(\text { phoxCOO})_{2}\right]\left(\mathrm{ClO}_{4}\right)$, the racemic mixture of the ligand rac-phoxCOO ${ }^{2-}$ is separated to form a mixture of iron(III) complexes, mer$\left[\mathrm{Fe}(S \text {-phoxCOO })_{2}\right]^{-}$and mer- $\left[\mathrm{Fe}(R \text {-phoxCOO })_{2}\right]^{-}$, which are related by an inversion center and are therefore present in a 1:1 ratio in the solid state. In Fig. 2 the isomer $\left[\mathrm{Fe}(S \text {-phoxCOO })_{2}\right]^{-}$is shown. This observation is similar to the chiral separation in the solid state as observed for the manganese complex of the ligand $\mathrm{Hphox} \mathrm{COOH}$ [6]. The asymmetric unit contains half a molecule of $[\mathrm{Fe}(\text { phoxCOO })]^{-}$located on a twofold rotation axis, half a perchlorate anion located on a mirror plane, and one molecule of protonated triethylamine. The phoxCOO ${ }^{2-}$ ligands are deprotonated at both the acid and the phenol moiety. The iron(III) center has a $\mathrm{N}_{2} \mathrm{O}_{4}$ coordination sphere with pseudo-octahedral geometry. The ligands are orthogonal, and coordinate to the metal center with the phenolate oxygen atom, the nitrogen atom of the oxazoline ring, and the carboxylate oxygen atom in a meridional fashion. The $\mathrm{Fe}-\mathrm{N}$ distance is $2.0597(15) \AA$ and the $\mathrm{Fe}-\mathrm{O}$ (phenolate) distance is $1.9188(13) \AA$; the $\mathrm{Fe}-\mathrm{O}$ (carboxylate) distance is significantly longer at $2.1010(13) \AA$. These distances are very similar to those in the $[\mathrm{Fe}(\mathrm{ehpg})]^{-}$complexes $\left(\mathrm{H}_{4} \mathrm{ehpg}\right)=$ ethylene- $N$,

Table 2

Selected bond distances $(\AA)$ and angles $\left(^{\circ}\right)$ for the complexes $\left(\mathrm{HNEt}_{3}\right)_{2}$ $\left[\mathrm{Fe}(\text { phoxCOO })_{2}\right]\left(\mathrm{ClO}_{4}\right)$ and $\left[\mathrm{Fe}(\text { phoxi } i \mathrm{Pr})_{3}\right]$

\begin{tabular}{lcll}
\hline (HNEt $\left._{3}\right)_{2}\left[\mathrm{Fe}\left(\right.\right.$ phoxCOO $\left._{2}\right]\left(\mathrm{ClO}_{4}\right)$ & {$\left[\mathrm{Fe}(\text { phoxiPr })_{3}\right]$} & \\
\hline $\mathrm{Fe}(1)-\mathrm{O}(17)$ & $1.9188(13)$ & $\mathrm{Fe}(1)-\mathrm{O}(17)$ & $1.9340(13)$ \\
$\mathrm{Fe}(1)-\mathrm{O}(28)$ & $2.1010(13)$ & $\mathrm{Fe}(1)-\mathrm{O}(37)$ & $1.9452(14)$ \\
$\mathrm{Fe}(1)-\mathrm{N}(23)$ & $2.0597(15)$ & $\mathrm{Fe}(1)-\mathrm{O}(57)$ & $1.9643(13)$ \\
$\mathrm{O}(17)-\mathrm{Fe}(1)-\mathrm{O}(28)$ & $159.30(5)$ & $\mathrm{Fe}(1)-\mathrm{N}(23)$ & $2.110(3)$ \\
$\mathrm{O}(17)-\mathrm{Fe}(1)-\mathrm{N}(23)$ & $84.94(6)$ & $\mathrm{Fe}(1)-\mathrm{N}(43)$ & $2.1602(18)$ \\
$\mathrm{O}(17)-\mathrm{Fe}(1)-\mathrm{O}(17) \mathrm{a}$ & $103.77(5)$ & $\mathrm{Fe}(1)-\mathrm{N}(63)$ & $2.1485(17)$ \\
$\mathrm{O}(17)-\mathrm{Fe}(1)-\mathrm{O}(28) \mathrm{a}$ & $89.53(5)$ & $\mathrm{O}(17)-\mathrm{Fe}(1)-\mathrm{O}(37)$ & $96.98(6)$ \\
$\mathrm{O}(17)-\mathrm{Fe}(1)-\mathrm{N}(23) \mathrm{a}$ & $102.72(6)$ & $\mathrm{O}(17)-\mathrm{Fe}(1)-\mathrm{O}(57)$ & $171.56(6)$ \\
$\mathrm{O}(28)-\mathrm{Fe}(1)-\mathrm{N}(23)$ & $76.59(5)$ & $\mathrm{O}(17)-\mathrm{Fe}(1)-\mathrm{N}(23)$ & $85.73(9)$ \\
$\mathrm{O}(28)-\mathrm{Fe}(1)-\mathrm{O}(28) \mathrm{a}$ & $82.63(5)$ & $\mathrm{O}(17)-\mathrm{Fe}(1)-\mathrm{N}(43)$ & $92.68(6)$ \\
$\mathrm{O}(28)-\mathrm{Fe}(1)-\mathrm{N}(23) \mathrm{a}$ & $94.09(5)$ & $\mathrm{O}(17)-\mathrm{Fe}(1)-\mathrm{N}(63)$ & $89.34(6)$ \\
$\mathrm{N}(23)-\mathrm{Fe}(1)-\mathrm{N}(23) \mathrm{a}$ & $167.73(6)$ & $\mathrm{O}(37)-\mathrm{Fe}(1)-\mathrm{O}(57)$ & $91.33(6)$ \\
& & $\mathrm{O}(37)-\mathrm{Fe}(1)-\mathrm{N}(23)$ & $92.04(9)$ \\
& & $\mathrm{O}(37)-\mathrm{Fe}(1)-\mathrm{N}(43)$ & $84.16(6)$ \\
& & $\mathrm{O}(37)-\mathrm{Fe}(1)-\mathrm{N}(63)$ & $172.09(6)$ \\
& & $\mathrm{O}(57)-\mathrm{Fe}(1)-\mathrm{N}(23)$ & $92.53(9)$ \\
& & $\mathrm{O}(57)-\mathrm{Fe}(1)-\mathrm{N}(43)$ & $89.62(6)$ \\
\hline
\end{tabular}

(a) Symmetry operation $1 / 2-x, y, 3 / 2-z$. 

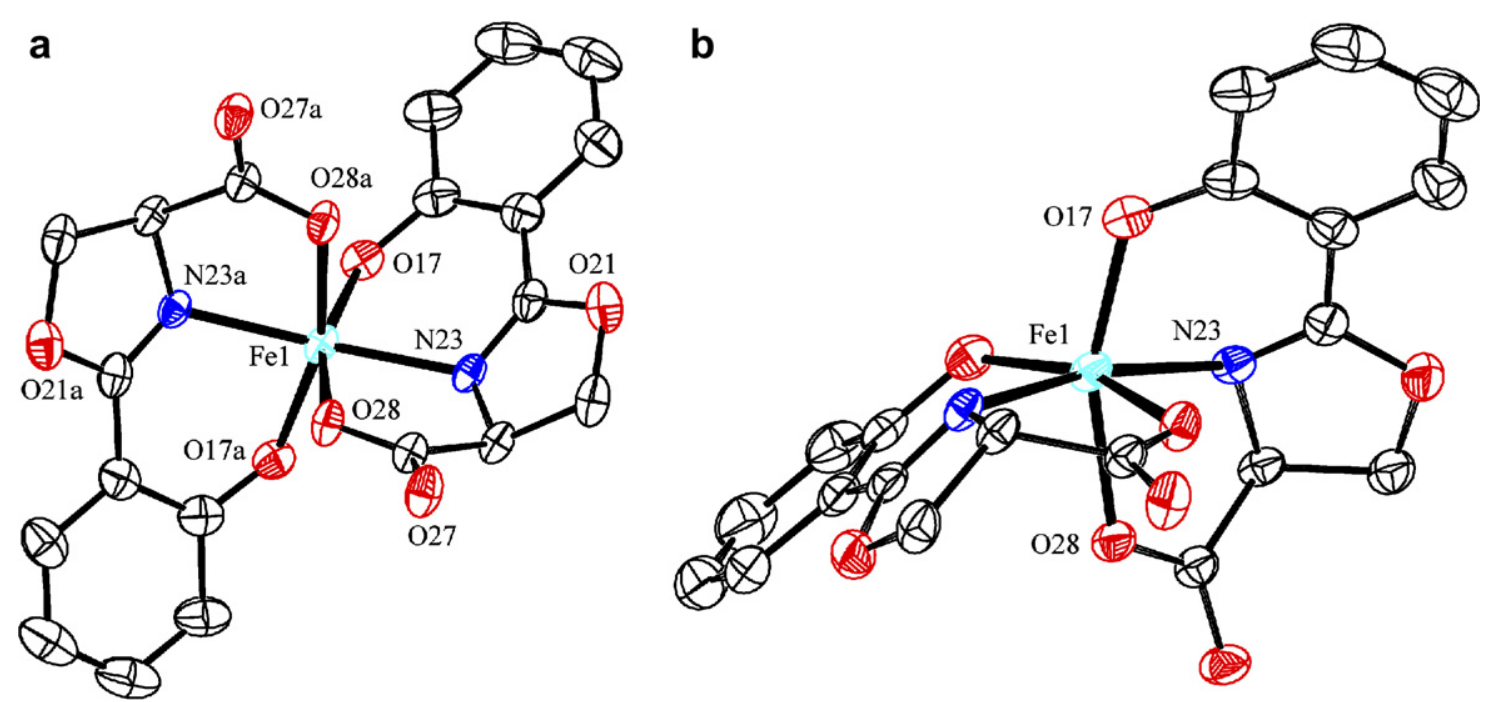

Fig. 2. ORTEP projections at $50 \%$ probability of the molecule of the complex, $\left(\mathrm{HNEt}_{3}\right)_{2}\left[\mathrm{Fe}(\text { phoxCOO})_{2}\right]\left(\mathrm{ClO}_{4}\right)$ showing the anionic isomer $m e r$ - $[\mathrm{Fe}(S$ phoxCOO $\left.)_{2}\right]^{-}$in different orientations. Hydrogen atoms are omitted for clarity. Symmetry operation: $a=1 / 2-x, y, 3 / 2-z$.

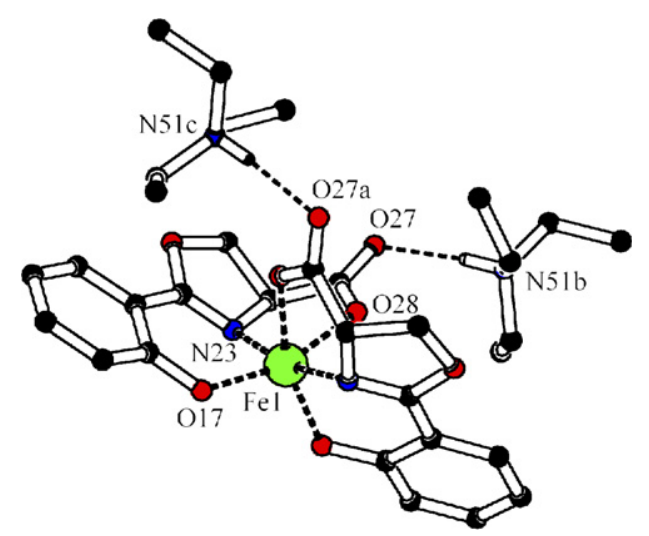

Fig. 3. A PLUTON projection of hydrogen bonding in the complex $\left(\mathrm{HNEt}_{3}\right)_{2}\left[\mathrm{Fe}(\text { phoxCOO})_{2}\right]\left(\mathrm{ClO}_{4}\right)$. Hydrogen atoms except those participating in hydrogen bonding are omitted for clarity. Symmetry operations: $a=1 / 2-x, \quad y, 3 / 2-z ; \quad b=1 / 2-x, 1 / 2-y, 1-z ; c=x, 1 / 2-y$, $1 / 2+z$.

$N^{\prime}$-bis((2-hydroxyphenyl)-glycine) [23] but are longer than in the complex $[\mathrm{Fe}(\mathrm{hped})]^{-}\left(\mathrm{H}_{4}\right.$ hped $=N, N^{\prime}$-bis $(2-$ hydroxyphenyl)ethylenediamine- $N, N^{\prime}$-diacetate) [24].

Hydrogen bonds are donated by the protonated triethylamine molecules to the deprotonated acid moieties of the iron complex. A discrete cluster of the composition $\left\{2\left(\mathrm{HNEt}_{3}\right) \cdot\left[\mathrm{Fe}\left(\text { phoxCOO}_{2}\right]\right\}^{+}\right.$is formed via these hydrogen bonds (Fig. 3) with a $\mathrm{N}(51) \cdots \mathrm{O}(27)$ distance of 2.773(2) A.

The arrangement of the phox $\mathrm{COO}^{2-}$ ligands in this iron complex is markedly different from the analogous manganese complex, $\left(\mathrm{H}_{2} \mathrm{NEt}_{2}\right)$ fac-cct-[Mn(R-phoxCOO $\left.)_{2}\right]$ [6] which shows a fac-cct arrangement of the ligands around manganese, the complex lacking any center or axis of symmetry. The complex $\left(\mathrm{H}_{2} \mathrm{NEt}_{2}\right)$ fac-cct-[Mn $\left.(R \text {-phoxCOO })_{2}\right]$ shows strong distortion in the phenol-oxazoline ligand backbone, whereas in the iron complex $\left(\mathrm{HNEt}_{3}\right)_{2}[\mathrm{Fe}$ (phox-
$\left.\mathrm{COO})_{2}\right]\left(\mathrm{ClO}_{4}\right)$ the phenol-oxazoline ligand backbone is rather planar. The dihedral angles between the phenol ring and the oxazoline ring for the two ligands in the iron complex is $7.97(10)^{\circ}$ as opposed to the dihedral angles of $25.08(16)^{\circ}$ and $21.09(13)^{\circ}$ in the manganese complex. However, in the iron complex $\left(\mathrm{HNEt}_{3}\right)_{2}\left[\mathrm{Fe}(\text { phoxCOO})_{2}\right]\left(\mathrm{ClO}_{4}\right)$ the phenolate-oxazoline chelate ring $(\mathrm{O} 17-\mathrm{C} 11-\mathrm{C} 12-$ $\mathrm{C} 22-\mathrm{N} 23$ ) is extremely tilted from the $\mathrm{Fe} 1-\mathrm{O} 17-\mathrm{N} 23$ plane by $37.26(8)^{\circ}$ (see Fig. 2) as compared to $15.66(14)^{\circ}$ and $12.80(12)^{\circ}$ in the manganese complex.

Structures similar to the above complex have been reported in literature with other metals in relevance to the coordination chemistry studies on metal complexes of the naturally-occurring siderophores (such as ferrithiocin) and their synthetic analogs $[25,26]$. The stereochemistry of the above complex is very similar to that of the complex $\left(\mathrm{HNEt}_{3}\right)\left[\mathrm{Cr}(\mathrm{dfft})_{2}\right]\left(\mathrm{H}_{2} \mathrm{dfft}=\right.$ Desferriferrithiocin $)$ [25]. In fact, the present iron complex is the first structurally-characterized analog for an iron-siderophore complex as established in mycobactins, albeit that the thiazoline ring is replaced by an oxazoline ring $[25,26]$.

An ORTEP projection the complex $\left[\mathrm{Fe}(\operatorname{phox} i \operatorname{Pr})_{3}\right]$ is shown in Fig. 4. The complex $\left[\mathrm{Fe}(\operatorname{phox} i \operatorname{Pr})_{3}\right]$ crystallizes in the centrosymmetric space group $P 2_{1} / c$. The structure of the iron(III) complex in an asymmetric unit is [Fe(phox$i \operatorname{Pr})_{3}$ ] containing three phox $i \mathrm{Pr}$ ligands coordinating to the iron center. The iron(III) center is in an $\mathrm{N}_{3} \mathrm{O}_{3}$ coordination sphere with pseudo-octahedral geometry. The $\mathrm{Fe}-\mathrm{N}$ distances are significantly longer than the $\mathrm{Fe}-\mathrm{O}$ (phenolate) distances; the distances are comparable to the usually observed $\mathrm{Fe}-\mathrm{N}$ and $\mathrm{Fe}-\mathrm{O}$ distances [27,28]. The three ligands are bound to the iron(III) center with equivalent donor atoms in meridional positions. The ligand containing $\mathrm{O} 17$ displays disorder, resulting in two different conformations of the iron complex. The two disorder components display an opposite chirality. In the following discussion 


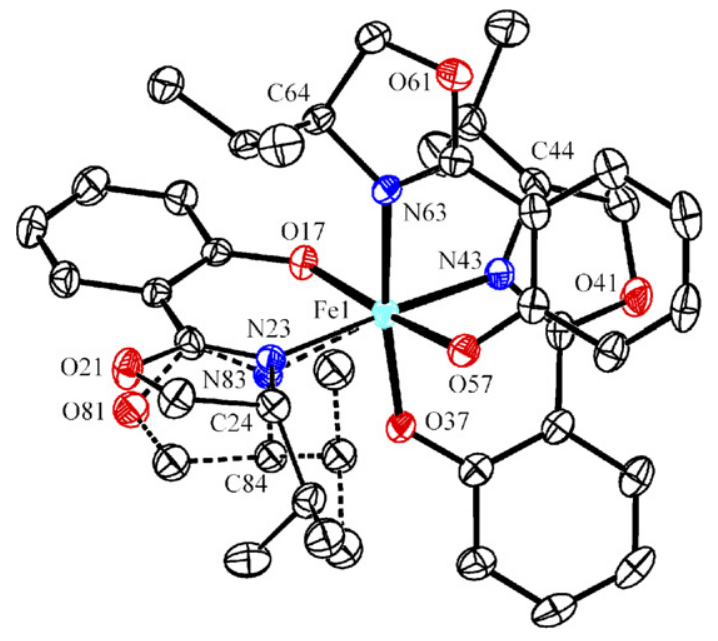

Fig. 4. ORTEP projection (with $50 \%$ probability ellipsoids) of a molecule of the complex mer-[Fe(phoxiPr) 3 (shown is the complex with $R R S$ configuration). The minor disorder component is indicated by dashed bonds. Hydrogen atoms are omitted for clarity.

the major disorder component (refined occupancy $92.9(2) \%$ ) is referred to as conformation A and the minor disorder component (occupancy 7.1(2)\%) as conformation B. For the complex displayed in Fig. 4, one ligand is in the $R$-configuration at atom $\mathrm{C} 44$, one is in the $S$-configuration (C64) and one is disordered over $R(\mathrm{C} 24$, conformation $\mathrm{A})$ and $S$ (C84, conformation B). The centric nature of the space group ensures that the inverted image of each complex is also present in the unit cell. Therefore, a total of four species are present in the crystal: molecules $[\mathrm{Fe}(R-$ phox $i \operatorname{Pr})_{2}(S$-phoxiPr)], abbreviated as configuration $R R S$, in conformation A (46.45\%), configuration $S S R$ in conformation A (46.45\%), configuration $R S R$ in conformation B $(3.55 \%)$ and finally configuration $S R S$ in conformation B $(3.55 \%)$.

Several iron(III) complexes containing an $\mathrm{N}_{3} \mathrm{O}_{3}$ coordination sphere have been reported in literature with the ligands 2-(2'-hydroxyphenyl)-oxazoline (Hphox) [27], 2-methylquinolin-8-olate [29], 1,1,1-tris(2-hydroxybenzylideneamino)-methylpropane [30], and 3(5)-methyl-5(3)(2-hydroxyphenyl)pyrazole $\left(\mathrm{H}_{2} \mathrm{phpz}\right)$ [28]. Most of these complexes also show a meridional arrangement of the like donor atoms, however, the $\left[\mathrm{Fe}\left(\mathrm{phox}_{3}\right)_{3}\right.$ complex has been proposed to be a mixture of meridional and facial conformations, due to the symmetry-related disorder observed in the crystal structure [27].

\subsection{Synthetic and spectroscopic aspects}

The synthesis of the ligands $\mathrm{HphoxCOOH}$ and $\mathrm{Hphox} i \mathrm{Pr}$ has been reported previously $[12,17]$. Reaction of iron(II) perchlorate with the racemic ligand $r a c-H p h o x C O O H$ in the presence of triethylamine results in the formation of the dark-red complex $\left(\mathrm{HNEt}_{3}\right)\left[\mathrm{Fe}(\text { phoxCOO})_{2}\right]$ which crystallizes as a double salt with $\left(\mathrm{HNEt}_{3}\right)\left(\mathrm{ClO}_{4}\right)$.

Reaction of the racemic ligand $r a c-H p h o x i P r$ with iron(III) perchlorate results in the straightforward forma- tion of the $\mathrm{ML}_{3}$ complex $\left[\mathrm{Fe}(\operatorname{phox} i \operatorname{Pr})_{3}\right]$. Solid-state ligand field spectra of both complexes show bands that are very similar in position. In both complexes, the intense band at around $510-517 \mathrm{~nm}$ can be assigned to the phenolate $(\mathrm{p} \pi) \rightarrow \mathrm{Fe}(\mathrm{III})(\mathrm{d} \pi) \mathrm{LMCT}$ transition [31], and the band at around $350 \mathrm{~nm}$ can be assigned to the phenolate $(\mathrm{p} \pi) \rightarrow \mathrm{Fe}(\mathrm{III})(\mathrm{d} \sigma)$ charge-transfer transition [31].

Coordination of the ligand to the metal center is confirmed for both complexes from the shift of the $\mathrm{C}=\mathrm{N}$ peak in the IR spectrum from around $1690 \mathrm{~cm}^{-1}$ in the free ligands to about $1610-1629 \mathrm{~cm}^{-1}$ in the metal complexes [32]. In addition, the symmetric and antisymmetric stretching vibrations of the oxazoline ring alkyl protons in both complexes are observed at 3016 and $3093 \mathrm{~cm}^{-1}$ in the complexes $(\mathrm{HNEt})_{2}\left[\mathrm{Fe}(\text { phoxCOO })_{2}\right]\left(\mathrm{ClO}_{4}\right)$ and $\left[\mathrm{Fe}(\text { phox } i \mathrm{Pr})_{3}\right]$, respectively [33]. The complex $\left(\mathrm{HNEt}_{3}\right)_{2}[\mathrm{Fe}$ (phox$\left.\mathrm{COO})_{2}\right]\left(\mathrm{ClO}_{4}\right)$ also shows a strong peak due to the presence of the non-coordinating perchlorate counter ion at $1089 \mathrm{~cm}^{-1}$.

\subsection{Catalytic alkane oxidations}

The catalytic activity of the complexes $\left(\mathrm{HNEt}_{3}\right)_{2}\left[\mathrm{Fe}(\text { phoxCOO })_{2}\right]\left(\mathrm{ClO}_{4}\right)$ and $\left[\mathrm{Fe}(\text { phox } i \mathrm{Pr})_{3}\right]$ has been tested in the oxidation of different alkanes (cyclohexane, cyclooctane, adamantane, toluene, ethylbenzene, cumene) with dihydrogen peroxide under ambient conditions. In all cases, a catalyst/substrate $/ \mathrm{H}_{2} \mathrm{O}_{2}$ molar ratio of $1 / 1000 / 100$ has been employed. The catalytic oxidation of alkanes was carried out by using an excess of substrate (RH) with respect to the oxidant to make sure that during the entire course of the reaction the concentration of the oxidized substrate $(\mathrm{ROH})$ is substantially lower than that of the substrate in order to minimize oxidation of $\mathrm{ROH}$. A large substrate $/ \mathrm{H}_{2} \mathrm{O}_{2}$ ratio was also expected to minimize decomposition of $\mathrm{H}_{2} \mathrm{O}_{2}$ (catalase activity). The complex $\left[\mathrm{Fe}(\text { phoxi } i \mathrm{Pr})_{3}\right]$ was found to be inactive in the oxidation of alkanes, whereas $\left(\mathrm{HNEt}_{3}\right)_{2}\left[\mathrm{Fe}(\text { phoxCOO})_{2}\right]\left(\mathrm{ClO}_{4}\right)$ shows modest catalytic activity in the oxidation of toluene, ethylbenzene and cumene (Table 3).

The oxidation of toluene catalyzed by $\left(\mathrm{HNEt}_{3}\right)_{2}[\mathrm{Fe}$ (phox$\left.\mathrm{COO})_{2}\right]\left(\mathrm{ClO}_{4}\right)$ gives benzyl alcohol $(10.1 \mathrm{TON})$ as the main product along with a small amount of benzaldehyde (3.2 TON), with a final conversion of $13.3 \%$ based on $\mathrm{H}_{2} \mathrm{O}_{2}$. Slightly higher activity ( $19.8 \%$ conversion based on $\mathrm{H}_{2} \mathrm{O}_{2}$ ) was observed in the oxidation of ethylbenzene; acetophenone (8.8 TON) and $R, S$-phenethyl alcohol (11 TON) were the main products. Cumene as substrate afforded 2-phenyl2-propanol (6.5 TON), acetophenone (5.2 TON) and $\alpha$ methyl-styrene (1.8 TON); a total conversion of $13.5 \%$ based on $\mathrm{H}_{2} \mathrm{O}_{2}$ was reached in this case. By comparison to the literature, the percentage conversion based on 100 equiv. of $\mathrm{H}_{2} \mathrm{O}_{2}$ in the range of $13-19 \%$ is a relatively high conversion of dihydrogen peroxide into the oxidation products. For example the percentage yield in the oxidation of toluene by the complex $[\mathrm{Fe}$ (tpaa) $]\left(\mathrm{ClO}_{4}\right)_{2}$ (tpaa $=$ tris- $[N-(2$-pyridylmethyl)-2-aminoethyl]amine) is reported to be $18.5 \%$ in total, 
Table 3

Alkane oxidations catalyzed by $\left(\mathrm{HNEt}_{3}\right)_{2}\left[\mathrm{Fe}(\text { phoxCOO })_{2}\right]\left(\mathrm{ClO}_{4}\right)^{\mathrm{a}}$

\begin{tabular}{|c|c|c|c|}
\hline Substrate & Product & $\mathrm{TON}^{\mathrm{b}}$ & $\begin{array}{l}\text { Conversion/based } \\
\text { on } \mathrm{H}_{2} \mathrm{O}_{2}(\%)\end{array}$ \\
\hline \multirow{2}{*}{ Toluene } & benzaldehyde & 3.2 & 13.3 \\
\hline & benzyl alcohol & 10.1 & \\
\hline \multirow[t]{2}{*}{ Ethylbenzene } & acetophenone & 8.8 & 19.8 \\
\hline & $\begin{array}{l}R, S \text {-phenylethyl } \\
\text { alcohol }\end{array}$ & 11.0 & \\
\hline \multirow[t]{3}{*}{ Cumene } & acetophenone & 5.2 & 13.5 \\
\hline & $\begin{array}{l}\text { 2-phenyl-2- } \\
\text { propanol }\end{array}$ & 6.5 & \\
\hline & $\alpha$-methyl styrene & 1.8 & \\
\hline
\end{tabular}

${ }^{a}$ Reaction conditions: catalyst:substrate: $\mathrm{H}_{2} \mathrm{O}_{2}=1: 1000: 100,5 \mathrm{ml} 1 \mathrm{mM}$ solution of the catalyst $(5 \mu \mathrm{mol})$ in acetonitrile.

${ }^{\mathrm{b}} \mathrm{TON}=$ turnover number of the product in mole product per mole catalyst obtained after $180 \mathrm{~min}$.

based on 20 equiv. $\mathrm{H}_{2} \mathrm{O}_{2}$ (i.e. 3.7 molecules of $\mathrm{H}_{2} \mathrm{O}_{2}$ converted to oxidation products) [34].

The absence of catalytic activity in the oxidation of cyclohexane, cyclooctane and adamantane suggest that the complex $\left(\mathrm{HNEt}_{3}\right)_{2}\left[\mathrm{Fe}(\text { phoxCOO})_{2}\right]\left(\mathrm{ClO}_{4}\right)$ is unable to hydroxylate alkanes with higher $\mathrm{C}-\mathrm{H}$ bond dissociation energies. It is generally accepted that any catalytic activity requires the presence of a minimum of one or two open sites for the binding and activation of the oxidant to take place $[35,36]$. Despite the hexa-coordination, the complex $\left(\mathrm{HNEt}_{3}\right)_{2}\left[\mathrm{Fe}(\text { phoxCOO})_{2}\right]\left(\mathrm{ClO}_{4}\right)$ is active in catalytic oxidations. This reactivity suggests that one or two of the ligand donors dissociate before or during catalysis, and points to the possibility that the structure of the original complex might not be conserved during the catalytic activity. Differences in the catalytic ability of the complexes $\left(\mathrm{HNEt}_{3}\right)_{2}\left[\mathrm{Fe}(\text { phoxCOO })_{2}\right]\left(\mathrm{ClO}_{4}\right)$ and $\left[\mathrm{Fe}(\text { phox } i \mathrm{Pr})_{3}\right]$ could possibly arise from a combination of a few factors. The strain associated with the tridentate binding of the phoxCOO ligand could lead to dissociation of one or more ligand donors, thus opening sites on the metal center for catalysis to take place. In addition, the carboxylate groups on the phoxCOOH ligand are electron-withdrawing as compared to the electron-donating nature of the isopropyl substituent on the phoxi $i$ r ligand.

\section{Concluding remarks}

The iron(III) complexes of the ligands $\mathrm{HphoxCOOH}$ and HphoxiPr exhibit interesting structural preferences owing to the chirality and denticity of the ligands. The iron complex of $R S$-Hphox $\mathrm{COOH}$ is octahedral, with two ligands bound in a meridional fashion in a tridentate manner. Both the dianionic ligands have same chirality, and are mutually perpendicular. The arrangement of the phox$\mathrm{COO}^{2-}$ ligands in this iron complex is markedly different from the analogous manganese complex, $\left(\mathrm{H}_{2} \mathrm{NEt}_{2}\right) \mathrm{fac}$ $c c t-\left[\mathrm{Mn}(R \text {-phoxCOO })_{2}\right]$ [6]. The crystal structure of the complex $\left(\mathrm{HNEt}_{3}\right)_{2}\left[\mathrm{Fe}(\text { phoxCOO})_{2}\right]\left(\mathrm{ClO}_{4}\right)$, is the first accu- rate structural model of iron complex of a siderophore ana$\log$ commonly observed in mycobactins. The reaction of the ligand $R S$-HphoxiPr with iron(III) perchlorate results in the formation of a $\left[\mathrm{FeL}_{3}\right]$ complex with an octahedral geometry, wherein three didentate ligands are bound with the $\mathrm{O}$ atoms in a meridional orientation to the metal center.

The complex $\left(\mathrm{HNEt}_{3}\right)_{2}\left[\mathrm{Fe}(\text { phoxCOO })_{2}\right]\left(\mathrm{ClO}_{4}\right)$ shows modest activity in the oxidations of alkanes, such as toluene, ethylbenzene and cumene, with relatively high conversions of dihydrogen peroxide, while the complex $\left[\mathrm{Fe}(\operatorname{phox} i \operatorname{Pr})_{3}\right]$ does not show any catalytic activity in alkane oxidations.

\section{Supplementary material}

CCDC 620093 and 620094 contain the supplementary crystallographic data for $\left(\mathrm{HNEt}_{3}\right)_{2}\left[\mathrm{Fe}(\text { phoxCOO })_{2}\right]$ $\left(\mathrm{ClO}_{4}\right)$ and $\left[\mathrm{Fe}(\operatorname{phoxi} \mathrm{Pr})_{3}\right]$. These data can be obtained free of charge via http://www.ccdc.cam.ac.uk/conts/retrieving.html, or from the Cambridge Crystallographic Data Centre, 12 Union Road, Cambridge CB2 1EZ, UK; fax: (+44) 1223-336-033; or e-mail: deposit@ccdc.cam.ac.uk.

\section{Acknowledgements}

This work has been carried out within the framework of the Council for Chemical Sciences of the Netherlands Foundation for Scientific Research (CW-NWO), through a grant from the special program "Aspasia". The authors thank Prof. Dr. Jan Reedijk for stimulating discussions.

\section{References}

[1] M. Sono, M.P. Roach, E.D. Coulter, J.H. Dawson, Chem. Rev. 96 (1996) 2841.

[2] M. Costas, K. Chen, L. Que, Coord. Chem. Rev. 200 (2000) 517.

[3] M.M. Abu-Omar, A. Loaiza, N. Hontzeas, Chem. Rev. 105 (2005) 2227.

[4] I.G. Denisov, T.M. Makris, S.G. Sligar, I. Schlichting, Chem. Rev. 105 (2005) 2253.

[5] S. Tanase, E. Bouwman, Adv. Inorg. Chem. 58 (2006) 29.

[6] M.D. Godbole, A.C.G. Hotze, R. Hage, A.M. Mills, H. Kooijman, A.L. Spek, E. Bouwman, Inorg. Chem. 45 (2006) 6713.

[7] M. Hoogenraad, H. Kooijman, A.L. Spek, E. Bouwman, J.G. Haasnoot, J. Reedijk, Eur. J. Inorg. Chem. (2002) 2897.

[8] M. Hoogenraad, K. Ramkisoensing, W.L. Driessen, H. Kooijman, A.L. Spek, E. Bouwman, J.G. Haasnoot, J. Reedijk, Inorg. Chim. Acta 320 (2001) 117.

[9] M. Hoogenraad, K. Ramkisoensing, S. Gorter, W.L. Driessen, E. Bouwman, J.G. Haasnoot, J. Reedijk, T. Mahabiersing, F. Hartl, Eur. J. Inorg. Chem. (2002) 377.

[10] M. Hoogenraad, K. Ramkisoensing, H. Kooijman, A.L. Spek, E. Bouwman, J.G. Haasnoot, J. Reedijk, Inorg. Chim. Acta 279 (1998) 217.

[11] M. Gomez, G. Muller, M. Rocamora, Coord. Chem. Rev. 195 (1999) 769.

[12] D.S.C. Black, M.J. Wade, Aust. J. Chem. 25 (1972) 1797.

[13] M.C. White, A.G. Doyle, E.N. Jacobsen, J. Am. Chem. Soc. 123 (2001) 7194.

[14] S. Tanase, C. Foltz, R. de Gelder, R. Hage, E. Bouwman, J. Reedijk, J. Mol. Catal. A 225 (2005) 161. 
[15] G.V. Nizova, B. Krebs, G. Süss-Fink, S. Schindler, L. Westerheide, L.G. Cuervo, G.B. Shul'pin, Tetrahedron 58 (2002) 9231.

[16] M. Fujita, L. Que, Adv. Synth. Catal. 346 (2004) 190.

[17] C. Bolm, K. Weickhardt, M. Zehnder, T. Ranff, Chem. Berichte 124 (1991) 1173.

[18] A.L. Spek, J. Appl. Crystallogr. 21 (1988) 578.

[19] G.M. Sheldrick, SHELXLs-86: Program for Crystal Structure Determination, University of Göttingen, Göttingen (Germany), 1986.

[20] G.M. Sheldrick, SHELXL-97: Program for Crystal Structure Refinement, University of Göttingen, Göttingen (Germany), 1997.

[21] A.J.C. Wilson, International Tables for X-ray Crystallography, vol. C, Kluwer Academic Publishers, Dordrecht, The Netherlands, 1992.

[22] A.L. Spek, J. Appl. Crystallogr. 36 (2003) 7.

[23] N.A. Bailey, D. Cummins, E.D. McKenzie, J.M. Worthington, Inorg. Chim. Acta-Articles 50 (1981) 111.

[24] S.K. Larsen, B.G. Jenkins, N.G. Memon, R.B. Lauffer, Inorg. Chem. 29 (1990) 1147.

[25] F.E. Hahn, T.J. McMurry, A. Hugi, K.N. Raymond, J. Am. Chem. Soc. $112(1990) 1854$.

[26] K. Langemann, D. Heineke, S. Rupprecht, K.N. Raymond, Inorg. Chem. 35 (1996) 5663.
[27] H. Kooijman, A.L. Spek, M. Hoogenraad, E. Bouwman, J.G. Haasnoot, J. Reedijk, Acta Crystallogr., Sect. C-Cryst. Struct. Commun. 58 (2002) m390.

[28] S. Tanase, E. Bouwman, G.J. Long, A.M. Shahin, A.M. Mills, A.L. Spek, J. Reedijk, Eur. J. Inorg. Chem. (2004) 4572.

[29] F.F. Jian, Y. Wang, L.D. Lu, X.J. Yang, X. Wang, S. Chantrapromma, H.K. Fun, I.A. Razak, Acta Crystallogr., Sect. C-Cryst. Struct. Commun. 57 (2001) 714.

[30] J. Reglinski, M. Patykiewicz, Acta Crystallogr., Sect. E.-Struct Rep. Online 58 (2002) M543.

[31] B.P. Gaber, V. Miskowsk, T.G. Spiro, J. Am. Chem. Soc. 96 (1974) 6868.

[32] D. Lin-Vien, N.B. Colthup, W.G. Fateley, J.G. Grasselli, The Handbook of Infrared and Raman Characteristic Frequencies of Organic Molecules, Academic Press Limited, London, 1991.

[33] G. Socrates, Infrared Characteristic Group Frequencies, Wiley, Bath, 1980.

[34] V. Balland, D. Mathieu, N. Pons-Y-Moll, J.F. Bartoli, F. Banse, P. Battioni, J.F. Girerd, D. Mansuy, J. Mol. Catal. A 215 (2004) 81.

[35] K. Chen, L. Que, J. Am. Chem. Soc. 123 (2001) 6327.

[36] K. Chen, M. Costas, J.H. Kim, A.K. Tipton, L. Que, J. Am. Chem. Soc. 124 (2002) 3026. 